\title{
Miejskość. Dom jako element wypetnienia przestrzeni publicznej
}

\section{Urbanity. A House as an Infill in the Public Space}

Streszczenie

om to jednocześnie „ognisko domowe" i budynek. W obu funkcjach pełniący istotną rolę $w$ sferze publicznej oraz budujący J ki charakter zabudowy. Wspótczesne procesy zachodzace w miastach redefiniuja to pojecie w odniesieniu do potrzeb zmie niającego się społeczeństwa. I te zmiany pojęcia miejskości właśnie stanowi główną oś rozważań.

Aldo Rossi w ikonicznym tekście Architektura miasta" przedefiniował pojẹcie ciagłości czy trwałości przestrzeni miasta pod katem budynku. To bardzo osobiste a jednocześnie oparte o rozważania teoretyczne podejście do zagadnienia miejskośc ( ru zabudowy miasta 19.wiecznego, poprzemysłowego, jakim jest Łódź, oraz wybranych miast europejskich o odmiennym charakterze rozwoju. Badania oparto o analizy kwartału miejskiego oraz jego roli w kształtowaniu miejskości przestrzeni, jak o odniesienia do charakteru architektury i roli społecznej pojedynczych budynków - domów w mieście). Przeprowadzona naliza pokazuje, iż pomimo odmiennych procesów społecznych zaskakująca jest niezmienność roli budynku w strukturze miasta i definiowaniu miejskości tej przestrzen

Abstract

The word house describes both a home and a building. Both roles are important in the public sphere. Both build the character of urban space.

Not only function but also the form of the built environment effectuate what we call urbanity. Contemporary developmen processes redefine the notion of what is urban as the needs of society change. And such differences in the comprehension Alhe urbanity notion, build the core of the article.

Aldo Rossi, in an iconic book, The Architecture of the City, decidedly redefined the notions of continuity or sustainability

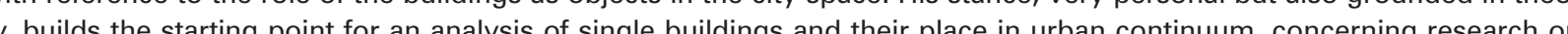
19-century post-industrial city (with examples from Lodz in Poland and other European cities with different development characteristics). The research base on the analysis of town quarters and their role in the creation of the urban space character thalso contains elements of building architecture and social roles analysis. In conclusion it is possible to state that even if existing differences in the development of society nowadays are profound, the role of the buildings in the city structure and urbanity is quite unchanging.

Stowa kluczowe: Miejskość, tkanka miejska, środowisko miesżant
Keywords: Urbanity, urban tissue, housing, social environment

"Dom prywatny w sposób oczywisty pierwotnie tworzony był dla rodziny jako dogodne miejsce odpoczynku. Nie bytby wystarczająco wygodny, gdyby wszystko czego wymaga rodzina nie znalazło sie pod jednym dachem. Duża liczba osób i rzeczy w mieście nie może być tak samo swobodnie pomieszczona, jak można to uczynic kie ograniczenia jak ściany dziatowe rynsztoki, tera ta miejskie, stuziebności, i tym podobne, które poworen iż rezultat nie zawsze jest zadawalajacy. Na terenach otwartych te ograniczenia nie istnieja: tu wszystko jest bardziej swobodne tam gdzie miasto jest restrykcyine. To, jako jedna z wielu przyczyn, sprawia dlaczego prywatne budynki w miescie powinny odrożniac się od tych na wsi."

Budynek, Dom, Miejskośc

w tytule książki Aldo Rossiego z lat 1960. '2, być może nawet nie w sposób w pełni zamierzony, koncentrując uwagę na pojedynczych oblektach, zmienil sposob postrzegania krajobrazu miejskiego. Budynki uznano za glowny element nadajacy miastu jego ksztat. Element sprawiajacy, ze miasto jest barWrzechodniom zán mo mieszkńcom jak i turystom zapamietywać poszczególne ulice, place i inne mieisca Pojecie domu jako budynku i domu jako ogniska domo wego czy rodziny (fonetycznie nierozróżnialne po polsku) pokazuje różnice znaczeniowe pomiedzy miejscem, któr ktoś „nosi w sobie” $i$ jest miejscem wymiany społeczne a fizycznym miejscem, bedacym materialna, konkretn przestrzenia budynku. Ten dualizm dotyczy także pojẹcia miejskości, które dotyczy wyrazu formalnego przestrzeni tak w wymiarze fizycznym, jak i społecznym.

Podobnie do Ado Rossiego, inny wspołczesny włosk architekt, Vittorio Lampugnani podkresla miejski wymiar architektury wyrastający z potrzeb społecznych I tak jak miasto stwarza najbardziej zroznicowane form bycia wspólnotą, czy zasady życia społecznego, domy miejskie reprezentują zróżnicowane formy kultywowanej bezstronności. Taka intymnośc budynku, w ktorym spędzamy każdy dzien naszego życia dostarcza szczególnej miejski, jak i zetniona w nim role pojedynczego krajobraz $z$ punktu widzenia użtkowika przestrzeni miejkiej powiazania pomiendzy obydwoma pojeciami (dom/budynek) pełnia istotna role w rozumieniu sposobu funkcjonowania miasta. Wielu badaczy wskazuje iz dzisiejsze poczucie sensu miejsca jest przezywane poprzez zbieran przeżycia i własne doświadczenie przestrzeni $0^{5} \mid z$ takie perspektywy, analiza miejsc poprzez lokalizacje budynków i ich znaczenia nabiera szczególnej wagi dla lepszego zrozumienia zasad kompozycii w kontekście urbanistycznym. Tym bardziej, iż jako mieszkańcy miasta, doświadczamy jego miejskosci głównie poprzez zagęszczeni unkcji i sposobów użykowania. Gdy stajemy się goscm wybieramy place, pojedyncze obiekty $i$ inne znaczące $h$ storycznie, estetycznie czy jedynie kulturalnie miejsca. I jak napisat w swojej podrożniczej opowieści o Rzymie, Robert Hughes, urodzony w Australii, krytyk sztuki „(... jedną z najistotniejszych rzeczy, które sprawiaja, że wspaniale miasto jest welkie nie tylko z powodu swej rozleglości, jest ilośc troski, detalu, obserwacji i miłosci skonenów miejskch. zainteresowania detalem - sprawia, ż rzeczy nabieraja znaczenia, to właśnie przykuwa wzrok, spowalnia krok zniecheca przechodnia do zbyt szybkiego przechodzenia obok I dzieje sie to bezwiednie, lub dziać sie tak powinno, że nie można przykładać takiej wagi do szczegółu bez zrozumienia wielu rzeczy o rzeczy istocie, o różnych kamieniach, różnych metalach, różnorodności drewn i innych materiałów budowlanych - ceramiki, szkła, cegły, tynku i całej reszty - to wszystko składa się na wnetrze i zewnętrzne powłoki budynku, jak się on starzeje, jak się private buildings in the city should be distinguished from those in the country.

House, Home, Urbanity

Used in the famous 1960s Aldo Rossi's book term the architecture of the city ${ }^{2}$, perhaps not fully designedly, has moved the focus from the cityscape main ele to singled buildings. Buldings saw as the main element which gives the city its shape. Which makes a tom vivid, givigung ory is shapen, Which res, sques, and other places.

The notions of a house and a home in the English The building and of a place people name their own, a site which could be a physical space or a social ex change. Both these meanings could be attributed to a city. And this, because its physicality shows itself in a material space, but its urbanity is also social.

As Aldo Rossi before, nowadays, another contemporary ltalian architect Vittorio Lampugnani stresses that the urban dimension of architecture arises from its social demand. ${ }^{3}$ And as a city forms the most intricated levels of togetherness, of rules of common life, the townhouses represent different kinds of cultivated neutrality. ${ }^{4}$ Such intimacy of a building in which we spend every day in our life gives us a Froms

a a significant role in the understanding of the workings of the city. Many researchers point out that today's sense of place is lived through collected memories and experiences ${ }^{5}$ And from such perspective an analysis of cases describing building locations and their significance for urban space is a matter better understanding of composition rules in the urban context. Because as citizens of a city, we experience its urban character predominately through the density of functions and uses. When vistors, we single out squares, buildings and over places of importance, historical, aesthetic, or just entertaining. And as described in the travelogue about Rome by Australian-born ar critic Robert Hughes (...) one of the vital things that makes a great city great is not mere raw size, but the mecipitated in its contents, including but not only its building. It is the sense of care eye, arrests the foot and discourages the paser-by from passing too easily by. And it goes without saying, or ought to, that one cannot pay that kind of attention to detail until you understand quite a bit about substance, about different stones, different metals, the variety of woods or another materials ceramic, glass, brick, plaster and the rest - that go to make up the innards and the outer skin of a building, how they age, how they wear: in sum, how they live, if they do live." ${ }^{11}$ 
zużywa: podsumowując, jak budynek żyje, jeśli żyje." "w...) gdzie miasto jako całosc wydaje się mieć podstawowe znaczenie, gdzie gęstosc i wielkosc są najważniejsze, problem zamieszkiwania wydaje się być mniej istotny, czy może jest mniej znaczący wobec innych funkcj życia miejskiego"

\section{Kwartat, Pierzeja, Pustka}

KWartal miejski zdefiniowany przez badaczy francuskic Panerai'a, Castex'a, Depaule'a i Samuels'a w ich książce w catości posswięconej temu zagadnieniu, tworzy "częśc cześci terenu poprzez ulice. W ten sposób, kwartał nie jest forma architektoniczna ale zbiorem niezależnych dziatek" " nie forma powstata a priori, ale (. ) systemem wynikowym, zdolnym do organizacji fragmentów terenów miejskich" pozostajacym w ścisłym zwiazku terenow miejskich" pozostającym w scisłym związku
$z$ systemem dróg, i opartym na wykształconym z systemem dróg, i opartym na "whyksztaiconym nieruchomościami, ktory warunkuje zmiany budyn Forma domu miejskiego wynika $z$ formy kwartału. Jes to szczególnie zauważalne $w$ Lodzi, gdzie historyczny rozwój kwartału prowadził od działki przeznaczonej pod pole uprawne dla Inu; dzialki polożonej za domem mieszkalnym tkacza, ktory ulega przekształceniu w zlokalizowan prostopadle do ulicy wielopiętrową kamienicę czynszową z wąskim dziedzincem. Podobne w typie rozwiąza funkcjonalnych i różniące się detalem architektonicznym kamienice tworza zwarte pierzeje wzdłuż ulic centrum miasta. Ale to ich architektura stwarza różnice. Formy architektoniczne dostarczaja zroźnicowanych wrażen Samo ich istnienie pozwala na identyfikacje fragment W mieście takim jak tódź to kwartat miejski defin charakter centrum. Przemi składajacych sie z kamienic, budynków użytecznośc publicznej, a nawet fabryk określał obraz miasta poprzez perspektywe prostych ulic i stosunkowo ujednolicon wysokość zabudowy. (II. 2) Jak udowadnia przykład nowych plomb mieszkalnych na ulicy Nawrot nie jest aż tak ważne jaką forme architektoniczną mają poszczególn budynki, ale to, że ulica zachowuje swoje proporcje, catościowy charakter przestrzeni. Wielopiętrowe budynk mogą byc ozdobione dziewietnastowiecznymi detalam zapożyczonymi z innych stylow historycznych lub kompletnie ich pozzawione, ale to one same okreslają charakter krajobrazu i jego miejskość. Pierzejowo lokowan kamienice pozbawione sąsiadów wydają się wyrwan $z$ kontekstu, jedynego sensu ich funkcjonowania w takie formie. (II.4) Podobnie jak, w Paryżu ujednolicona napoleońska pierzeja dominuje wyobrażenie o mieście prze obrażonym przez Hausmann'a. Jak w Antwerpií, gdzie pierzejowa zabudowa przypomina nierowne uzębienie dokumenujac $w$ postaci rożnej wysokości budynków nych miastach, gdzie ich zapamietany obraz to to co odmienne na tle niewyróżniajace sie poprzez jednostkowa kreację zabudowy, która jednocześnie jest niezbędna dla miejskiego charakteru przestrzeni.

To co wydaje sie najważniejsze dla pojẹcia miejskości to istnienie sfery publicznej i budynki użytecznosci publicz-
1...) where the city as a whole seems to be of priimportance, or at least becomes less focused with respect to the other functions of urban life'.

\section{A Quarter, a Frontage, a Void}

Urban block as defined by Panerai, Castex, Depaule, and Samuels in their book fully dedicated to this is sue, builds 'a part of an urban area 'solated' from the neighboring parts of the territory by streets. Thus, the block is not an architectural form, but a group of interdependent building plots', 'not an a priori form but (...) a resulting system, capable of organizing parts of the urban territory' staying in strict relationship with road system, and based on 'fixed legal and real estate framework, which conditions the evolution of buildings and the types of use by the inhabitnts'.

The townhouse form results from the form of a city block. It is particularly visible in Łódź, where his torical development has lead from flax fields placed behind weaver's houses to multi-story tenement houses with long, narrow courtyards perpendicular to the street. Standardized, repeatable in functiona solutions, but differing in the ornament the houses line the streets in the city center. But still, it is the arat forture that makes the direrence. The architecturexorns deflue a variety of experiences. Their mere existence allows the identifiction of space, allows rembering and recognition.

列 la inside center quarters gets somehow unified image becaus of the long perspectives of the streets and elatively similar heights of the buildings. (II. 2) It is not 0 important what form the singular hous takes as the new fillins in the Nawrot street show). Wha matters is the narrowness, the longsh section of the treets, the overll character of the space. Multi-story buildings could be incrusted with 19.-century mold ings and historical elements borrowed from previous

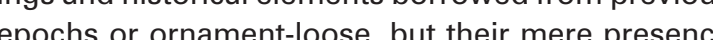
along the street determines the cityscape and the urban feeling of the surroundings. When without neighboring buildings such houses look forlon, strictly the context defines their existence. (II.4) As Paris, the Napoleonian standardized street imas dominates the depiction of the Hausmann city. As in Antwerp, where regular street frontages remain of uneven teeth showing the differences in aesthetic and economy development stages. As in other cites, where their memory illustrates the extraordinary against a background of houses insignificant in their singular form, but indispensable for the urban space characte

But what is most important for the perception of rbanity are public functions and public buildings. In Łódź, such urban functions usually located nej. W Łodzi tego typu funkcje zwykle były umieszczane w budynkach historycznych - gow ckich (okreslanych mianem palaców). W związku z ty instytucje użyteczności publicznej rzadziej otrzymywaly własne siedziby o specjalnej formie architektonicznej. Ta więc w krajobrazie miejskim, budynki o najważniejszych funkcjach ogólnych nie odróżniają się formą od tych, które wyke mają charakter prywatny. To czyni krajobraz miasta wyjatkowym a jednoczesnie dla wielu jest to zaskakujace cje struktury i funcjo mieszkńców miasta Powoduje tż pomieszanie odbioru nieformalnego i odświetnego, reprezentacyinego cha rakteru przestrzeni, a centrum miasta nie jest odbierane jak przestrzeń miast historycznych o wyraźnym publicznym charakterze kompozycji urbanistycznej. W pewnym stopniu peryferia miasta $\mathrm{i}$ jego centrum upodabniaja sie jedynie niewielkie różnice decyduja o wiẹkszej miejskości przestrzeni. Ponieważ nawet funkcje zwykle lokowan centralnie, jak szkoły wyższe czy administracja publiczna nie mogą być tu traktowane jako wyróżnik.

Zwykle, zabudowa mieszkaniowa lokowana jest przede wszystkm w niedookreslonej przestrzeni obrzeży miasta. To tu dom mieszkalny stanowi najistotniejszy element kompozycji. Tkanka miejska ma lużą strukture a przebieg ulic wytyczają nie pojedyncze obiekty a ogrodzenia czy szpalery drzew. Zmiana charakteru struktury przestrzennej zmienia sposób definiowania miejskości W kompozycji urbanistycznej niezbędna jest pewna intensynosc i kompaktowośc przestrzeni. To wlaśn wyraża gtównie poprzez uwarunkowania spesten Bliskość bycie razem, pośpiech i goraczka codziecznych działań określajacych rytm ìycia miejskiego wptywa istotnie na identyfikacje miejskego charakteru zabudowy. Ta różnica jest wyjątkowo widoczna kiedy porównujemy odmienne sytuacje przestrzenne, jak w przypadku osied la Heimat Siedlung we Frankfurcie nad Menem. Mimo peryferyjnego polozienia to modernistyczne osiedle ma zdecydowanie miejski charakter. Linearna kompozycja 9 rzędów równoległych budynków mieszkalnych daje efekt zwartego zespołu. Architekt i urbanista Erns May (1886-1970), w tym czasie zatrudniony w urzędzie miasta, stworzyl program dla zabudowy mieszkaniowe "Das Neue Frankfurt". W jego ramach architekt Franz Roeckle (1879-1953) opracował projekt osiedla, w którym znalazło się 1000 jednostek mieszkalnych. Zbudowan w latach 1927-1934 osiedle stanowi zachodni fragmen osiedla Ried w dziehicy Frankurtu Sachsenhausen Osiedle ma charakter "miasta w miescie" i zdecydofunkcje mi zaniowe Niektóre z nich maja az $250 \mathrm{~m}$ długości. Wyraz architektoniczny stosunkowo nieozdobnych fasad jest bardzo silny. Wszystkie wojścia zostaly ulokowane od dziedzińców z trawnikami o 15. m sze rokości. Elewacje ujednolicaja wydłużone przeszklenia od strony południowej. Wyższe budynki usytuowano na obrzeżach, niższe wewnattrz osiedla. Rytm zwężo nych wjazdów kolejnych ulic hipnotyzuje konsekwencja kompozycji. Uliczki, każda obsadzona głównie drzewam liściastymi jednego gatunku, noszą ich nazwy. Całośc jest imponująca i niepozostawiająca wątpliwości co do in historical factory owner's villas (so-called palacs) rarely architectonic form. In such a way, the house alinced its meaning from home in an institution. So in the landscape, the buildings bearing the most ers ers which contain only private uses making the cher which contin only private us many. And this makes a significant distinction in the perception of the structure and the workings of the city, whic has an unprecedented impact on the inhabitants insight. So the image of urbanity starts to be confused with the image of domesticity, and the urban center cerve the periphery and its buildings start to be similar the denity. Eventhe recognition of space ur-

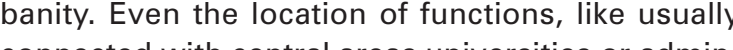
istrative Ordinarily, thes, cannot be used as an identifier. Ordinarily, the nondescript city fringe is the site whe house as the chosition element is an important criterion. The conty singular objects the streets otherwise defined more This change is the main issue in defining fronts. in terms of un man issue in defining urbanity. . the urba feling is most important. It catches

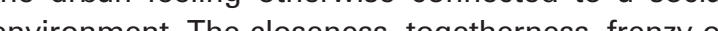
everyday dealings which determine the rhythm of urban life are essential for the recognition of the urban character of space.

Such a difference is especially visible when compared with other spaces as the Heimat Siedlung in Frankfurt am Main. Even if located peripherally, this Modern Movement housing estate has a definite urban fleur. The linear composition used in the design 9 parallel rows of houses builds in effect a dense urban shape. Architect and urban planner Ernst May (1886-1970), at the time serving in Frankfurt city council, was responsible for a housing program called Das Neue Frankfurt. Architect Franz Roeckle (1879-1953) prepared the estate design in the frame f this housing program. The estate of 1000 flats built from 1927 till 1934, is a western part of Ried Estate in Frankfurt Sachsenhausen. ${ }^{9}$ The housing estate has a city in the city appearance. And it has a definitely urban character even as the houses are strictly residential. Some of the houses are 250 meters long The facades are strong in the relatively plain impression they give. All house entrances are located in the courtyards with waste $15 \mathrm{~m}$ broad lawns. Elongated glassing in the south stresses the unity of design. The higher buildings facing main streets enclose smaller, more inner ones. The rhythm of narrowed tremely consequent in the design. The streets are 
krystalizuja strukturę miasta i wraz z znaczącymi spofecznie $\mathrm{i}$ kulturowo budynkami pozostaja w pamięci o wyrazie przestrzennym danego miasta. Te przestrzenie budują ramę dla życia miejskiego mieszkańców jak obywateli i przedsiębiorców. I tu ponownie Łódź jawi się jako odmienny przykład. Place $w$ strukturze miasta nie odgrywają znaczącej roli. Te, które istniały w strukturze miasta pełnity funkcję placów targowych i ich przeobrażenie $w$ bardziej reprezentacyjna przestrzeń właściwi nie zaistniało $w$ pełni. Jedynym wyjątkiem, dość przypadkowym w kategoriach kompozycji urbanistycznej, budynków, jest gtówny plac ulokowanego w pofabrycz budynków, jest glówny plac ulokowanego w pofabrycz faktura. A w wyniku przeobrażeń gtównie ekonomicznych, ostatnich lat dawne place wypetnity zabudomiczhyle targowe i place te przestały spełniać role otwarte hale targowe i place te przestały spełniac role otwarte
przestrzeni publicznej. W innych miastach, place - starannie zaprojektowana pusta przestrzeń uzupetnia te zabudowana, wypełnioną budynkami.

Ale wyjątki potwierdzają regułe, i wzajemna zależnośc pomiędzy budynkami a pustymi przestrzeniami pozostaje podstawową zasadą projektowania kompozycji urbanistycznej, historycznie i współcześnie.

„Ponieważ uważam, ze postęp dotyczący wiedzy o mie ście moze byc prawdziwy i skuteczny jedynie jesli nie usifujemy zredukowac miasta do jednego z jego aspektów tracac z oczu ich szersze znaczenie."

\section{Miejska przestrzeń jako dom}

Tożsasc charakteru miejskości umyka czasem możliwoścítczesna tendencie do rnalitycy przestrzeni opisuja życia miejkiego. Codziennozynnóci rozgryajaci we fragmentach przestrzeni mieiskie I pozornie nie tylko powierzchownie, brakuje całościowych powiazan. Czesto uważa sie, że przestrzeń miasta powinna umożczynności jako ciagłego procesu, gdzie inni ludzie i bu dynki pozostaja niezmienni (w sensie zmian dotyczacych przeobrażeń gentryfikacyjnych).11 Autentyczna miejskość zanika kiedy taka ciągłość przestrzenna i społeczna ulega przerwaniu. Wartość marketingowa przypisywan wspớcześnie rownież miastom takì zmienia sposób rozumienia miejskosci. Chociaz taki merkantylny sposób postrzegania miasta moźna odnaleźc równiez w opisie początkow Lodzi w "Ziemi obiecanej" Reymonta. Łódź jako miasto sięga roku 1423. Ale dopiero po wprowadzeniu przemysłu tekstylnego zaczęła by odbierana jako prawdziwy organizm miejski. Wcześnie wiejski charakterterenów miejskich i liczba mieszkanców (767 w nie dawał podstaw to twierdzeń o miejskości osady. dodajac zawsze do nazwy tódź określenie mijasto tódź. Tak wić niek nie pochodzit, czy przyjezdża z todzi a zawsze z miasta todzi. To określenie zwyczajowo jest stosowane potocznie również dziś A samo miasto uzyskato prawdziwie zageszczona miejska strukture jedynie w samym centrum. Tereny obrzeży wciaż mają charakter nieco małomiasteczkowy. Ale w gęstość zabudowy pery- shape. They create the urban frame for the life of inódź provides here a different example. The squares in the city were practically nonexistent. The only ones which were included in the structure were market places and their change into more formal space never really succeeded. The only rather accidental exception remains the not so composed as tearin down resulted square in Manufaktura, the shopping and cultural center created in the place of a factory. And in the latest development, the old squares go filled with covered markets and stopped to provide open public space. In any other city, the public squares - carefully designed voids supplement the filled with buildings space.

But exceptions prove the rule and the interplay be tween buildings and open spaces remains the ground rule of the urban composition throughout history.

'For I am convinced that progress concerning knowedge of the city can be real and efficacious only if we do not try to reduce the city to any one of its partial aspects, thereby losing sight of its broader signif-

\section{Urban Town Space as Home}

The identity of an urban character of a city is sometimes very evasive to be put in words. The contemporary space analysts describe a kind of pocketization of present urban life. Everyday life plays in fragments of urban space. And seemingly, not on the such rogether as a whole. It is often understood as that ine sheuld allow a continuous process whe oupeop people and buldings ren The make value atributed nowas to the cities tho ater the understanding of the ur ban che cives of the space. But such mercantile view of a city could e found also in the depiction of tódź in Whysty Reymon's novel describing the city's foundation as rextile industry capita. 12 tótź is a city capted

already from 1423. First, after extile industry introduction has begun it started perceived as a real urban organism. Before the cter of the city proper and the number of citizens (about 767 in 1821, when the New Town was ocated) never gave the reason to boast about urbanity of the town. And the rural area neighbors stated this change in being townish in addition to the word the city to the name tódź. So from now on nobody came from Łódź but from the city of tódź. This customary wording still exists in the commonly used language. The city itself became dense and ured but only in the city center. The outskirts beware til now their more small-town character. But the peripheral areas were denser in their structure than the central ones. It was the result of the delayed incorporations of such suburbs as Batuty (regarded as a vil- ferii była historycznie większa niż terenów centralnych. opoznionych inkorporacji takich przedmiesc jak Baluty (ktore pozostawaly wsią). Te przedmiejskie samodzielne organizmy nie włączane w strukture miasta podlegały innym przepisom prawnym dotyczacym zabudowy. Prawdopodobnie z tęsknoty za większa metropolitalnością wynika zatem chęć podkreśleni miejskości choćby przez coroczne dodawanie centyme ka upamiętniającego nathie praw miejskich. (II. 1)

nny problem napotykamy gdy analizujemy rozwój strukprzestzen. The miejskóć jest rodzajem prowizorycznej inscenizaci $z$ realnej rzeczywistości przemieniła sie w cel polityk kulturowej. Stusznie zakłada że nasza fascynacja mitem Starego Miasta (w znaczeniu miasta prawdziwego) do prowadziła nas do rzeczywistości dzisiejzzych peryfeil a nasze zrozumienie tego szczególnego świata jest zaburzone. Zwarte, spójne, energooszczeedne i przyjazn użytkownikom Stare Miasto (w odniesieniu do skali wymiarów, granic przestrzennych) jest dziś niereplikowalne ze względu na zróżnicowane, zbyt daleko idące zmiany: ekonomiczne, kulturowe, polityczne i spoleczne. ${ }^{12}$ Sieverts nazywa nowopostałą formę miejskośc krajobrazem zurbanizowanym alko ukrajobrazowionym miastem. Takie okreslenie dobrze oddaje charakter takich między-przestrzeni tworzących miasto bez przestrzennego charakteru miejskiego. A niektorzy badacze (jak np. Robert Fishman'13) w ogole uważaja, iż ducha dzisiejszych czasów bardziej wyrazają przedmieścia niż iko niczne budynki. Takie stwierdzenie uzasadnia sugestię, ze waściwą miejskośc także lepiej wyrażają te niedoce niane tereny miejskie. Ale dzisiejsze peryferia miast rozwijaja się W sposób niekontrolowany, a jeżeli pozornie wanizacia terenów podmiejkich przynosi dramatyczne zmiany krajobrazu naturalnego i kulturowego.

i chodza bezprawnie. Ale ma to ogromne znaczenie zakonotacji znaczenia pojęcia miejskości.

PRZYPISY

Alberti L. B., On the Art of Building in Ten Books., Book V On the Works
of Individuals, The MIT Press, Cambridge, MA 1988 . https:///catena.bgc Rossi, A. The Architecture of the City, The MIT Press, Cambridge, Mas-
sachusetts and London, England 1984, wydana po raz pierwszy w roku 1966
3 Takie podejeście moina również odnaleźć u polskich autorów, jak np. Jaa
cek Gyurkowich (Miejskość miasta, Czasopismo Techniczne, z-2/2007, s. $105-118$

( Zukin, S. Naked C Otstilidern 2015, ss. $100-101$. A A Dentic Urban Places. Ox ford University Press, London 2010, Rykwert, I., The Seduction of Place 6 Hughes R., Rome. Weidenteld \& Nicolson, GB 2011, s. 11
7 Rossi, A., The Architecture of the City, The MIT Press, Cambridge, Mas sachusetts and London, England 1984, s. 85
8 Panerai P., Castex J., Depaule J.Ch., Samuels I., Urban Forms. The Death
and Life of the Urban Block., Architectural Press, Oxtord 2005, ss.162-16

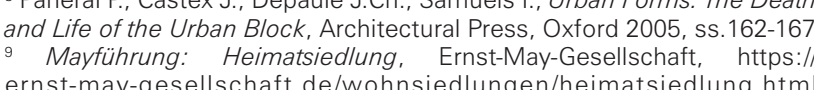
ernst-may-gesellschaft.de/wohnsiedlungen/heimatsiedlung.htm
(Dostep: 15.05.2019) ${ }^{\circ}$ Rossi, A., The Architecture of the City, The MIT Press, Cambridge, Mas
sachusets and London, England 1984, p. 27 lage). These suburban organisms too long developed mo (n)

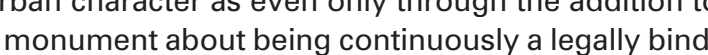
ing town. (II. 1)

A different problem emerges when city structures development is analyzed. And Thomas Sieverts describing today's in-between city structures advanced a thesis that contemporary urbanity has to be a staging, from an existing reality it changed into a cultura politics aim. Rightly, Sieverts states that our fascination with the mythos of the Old City veiled to us the reality of present-day peripheries and our comprehension of this unique world is distorted. Compact, energetically coherent, user-friendly (scale, dimensions, space borders) Old City is not contemporary replicable because of the multifaceted, too far gone changes in economy, culture, politics, and society. ${ }^{13}$ Sieverts calls such a city form an urbanized landscape or landscaped city. Such description catches in a good way the essence of such in-between-spaces building a city but without real urban character. An some researchers (f. ex. Robert Fishmanan') tend to believe that the spirit of our times is better shown in suburbs than in great buildings - architectural icons. It would suggest that the urban character of a city is also better expressed in the olherwise underestis form themsetves in an uncontrolled way or cise in in, seemingly controlled, but in really, chaolic way. The in aramatic changes in the culturat and natura landscape.

And it makes no difference if the process is planned r lawless. But it makes a huge difference in connotations of urbanity.

ENDNOTES

1 Alberti L. B., On the Art of Building in Ten Books., Book V On the
Works of Individuals, The MIT Press, Cambridge, MA 1988. https://

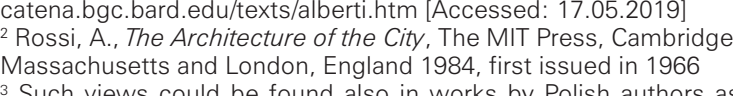
Such views could be found alaso in works by Polish authors as
t. ex. Jacek Gyurkowich (Miejksóć miasta, Czasopismo Techniczr. ex. Jacek Gyurkowich
ne, z-2/2007, su. 105-118) Lampugnani V. M. Radikal Normal. Positionen zur Architektur der
Stadt, Hatje Cantz Verlag, Ostfildern 2015, p. 100-101 Stadt, Hatje Cantz Verlag, Ostrildern 2015, p. 100-101
5 Zukin, S. Naked City: The Death and Life of Authentic Urban Plac es. Oxford University Press, London 2010 . R R k kert, J., The Seduc "Hughes R., Rome, Weidenfeld \& Nicolson, GB 2011, p. 11
Rossi, A., The Architecture of the City, The MIT Press, Cambridge.

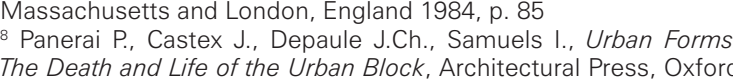
2005, p. 162 - 167 Maytürrung: Heimatsied/lung, Ernst-May-Gesellschaft, https://
ernst-may-gesellschaft.de/wohnsiedlungen/heimatsiedlung.htm (Accessed: 15.05.2019)
10 Rossi, A., The Architecture of the City, The MIT Press, Cambridge Massachusetts and London, England i 984, p. 27
"A perspective strongly underlined in the context of gentrification "ex. by Sharon Zukin in her book, op.cit., p.6
12 "The Promised Land", Reymont's novel from 1899 
${ }^{11}$ Pogląd silnie wyrażany np. przez Sharon Zukin, op. cit., s. 6

12 Sieverts T., Zwischenstadt. Zwischen Ort und Welt, Raum und Zeit, Stadt und Land, Bauverlag Gütersloh Berlin, Birkhäuser, Basel, Boston, Berlin 2008, ss. 37, 23, 174

13 Fishman R. Urban Utopia in the Twentieth Century: Ebenezer Howard, Frank Lloyd Wright, Le Corbusier, The MIT Press, Cambridge 1982, s. 6

\section{LITERATURA}

[1] Alberti L. B., On the Art of Building in Ten Books., Book V On the Works of Individuals, The MIT Press, Cambridge, MA 1988. https://catena.bgc.bard.edu/texts/alberti.htm [Accessed: 17.05.2019]

[2] Fishman R., Urban Utopia in the Twentieth Century: Ebenezer Howard, Frank Lloyd Wright, Le Corbusier. The MIT Press, Cambridge 1982 [3] Gyurkowicz J., Miejskość miasta, Czasopismo Techniczne, z-2/2007, s. $105-118$

[4] Hughes R., Rome, Weidenfeld \& Nicolson, GB 2011

[5] Lampugnani V. M., Radikal Normal. Positionen zur Architektur der Stadt, Hatje Cantz Verlag, Ostfildern 2015

[6] Panerai P. Castex J., Depaule J.Ch., Samuels I., Urban Forms. The Death and Life of the Urban Block, Architectural Press, Oxford 2005

[7] Rossi, A., The Architecture of the City, The MIT Press, Cambridge, Massachusetts and London, England 1984

[8] Rykwert, J., The Seduction of Place: The History and Future of the City. Oxford University Press, Oxford 2004

[9] Sieverts T., Zwischenstadt. Zwischen Ort und Welt, Raum und Zeit, Stadt und Land, Bauverlag Gütersloh Berlin, Birkhäuser, Basel, Boston, Berlin 2008

[10] Zukin, S. Naked City: The Death and Life of Authentic Urban Places. Oxford University Press, London 2010
13 Sieverts T., Zwischenstadt. Zwischen Ort und Welt, Raum und Zeit, Stadt und Land, Bauverlag Gütersloh Berlin, Birkhäuser, Basel, Boston, Berlin 2008, p. 37, 23, 174

${ }_{14}$ Fishman R., Urban Utopia in the Twentieth Century: Ebenezer Howard, Frank Lloyd Wright, Le Corbusier, The MIT Press, Cambridge 1982, p.6

\section{BIBLIOGRAPHY}

[1] Alberti L. B., On the Art of Building in Ten Books., Book V On the Works of Individuals, The MIT Press, Cambridge, MA 1988. https:// catena.bgc.bard.edu/texts/alberti.htm [Accessed: 17.05.2019]

[2] Fishman R., Urban Utopia in the Twentieth Century: Ebenezer Howard, Frank Lloyd Wright, Le Corbusier, The MIT Press, Cambridge 1982 [3] Gyurkowicz J., Miejskość miasta, Czasopismo Techniczne, z-2/2007, s. $105-118$

[4] Hughes R., Rome, Weidenfeld \& Nicolson, GB 2011

[5] Lampugnani V. M., Radikal Normal. Positionen zur Architektur der Stadt, Hatje Cantz Verlag, Ostfildern 2015

[6] Panerai P., Castex J., Depaule J.Ch., Samuels I., Urban Forms. The Death and Life of the Urban Block, Architectural Press, Oxford 2005

[7] Rossi, A., The Architecture of the City, The MIT Press, Cambridge, Massachusetts and London, England 1984

[8] Rykwert, J., The Seduction of Place: The History and Future of the City. Oxford University Press, Oxford 2004

[9] Sieverts T., Zwischenstadt. Zwischen Ort und Welt, Raum und Zeit, Stadt und Land, Bauverlag Gütersloh Berlin, Birkhäuser, Basel, Boston, Berlin 2008

[10] Zukin, S. Naked City: The Death and Life of Authentic Urban Places. Oxford University Press, London 2010 